\title{
NOLL CONTEMPLA NARCISO: A ESCRITA EM REFLEXO
}

Francisco Renato de Souza*

RESUMO: Este artigo investiga a relação entre autor e obra na composição da escrita literária dos romances Bandoleiros e Solidão continental, de João Gilberto Noll, a partir do processo de elaboração escritural que se desenvolve en abyme nessas obras nas quais a não-nomeação e a ocultação da identidade do narrador pela ambígua nomeação de João, assim como a sua recusa pela propria imagem e a busca do seu reflexo no outro, são investigadas como espelhamento do desenvolvimento da autoria da escrita ficcional. Tomando como base metodológica a perspectva do escritor francês Maurice Blanchot, na qual a literatura, pautada pela ambiguidade, deixa de ser um modo de representaça to mundo do aur do mundo do autor para se tornar upresentaça de si mesma pretende-se conjuntamente à investigação acima citada estabelecer uma relação entre o narrador nolliano e a figura mitológica de Narciso, em que o mito grego é esvaziado pelo texto de Noll de qualquer sentido que Ihe fora previamente atribuído, podendo então ser revestido por outras abordagens de leitura.

PALAVRAS-CHAVE: Noll; Narciso; Blanchot; Autoria; Escrita.
* paconato_@hotmail.com

Doutor em Teoria Literária pelo Departamento de Ciência da iteratura da Universidade Federal do Rio de Janeiro.

RESUMÉ: Cet article aborde le rapport entre l'auteur et l'œuvrequan à la composition de l'écriture littéraire des romans Bandoleiros et Solidão continental, de João Gilberto Noll, à partir de la méthode de conception de l'écriture mise en abyme dans ces œuvres, dans lesquelles l'absence de désignation et la dissimulation de l'identité du narrateur par la dénomination ambiguë de João, tout comme le refus de sa propre image et la recherche de son reflet dans l'autre, sont étudiés comme s'il s'agissait du miroitement du développement de la création de l'écriture fictionnelle. En utilisan comme support méthodologique la perspective de l'écrivain fran. cesse d'etre un mode de representation du monde de l'auteur pour devenir une presentation d'elle-meme, nous avons l'intention conjointement a la recherche citee ci-dessus d'établir une relation entre l'auteur nollien et la figure mythologique de Narcisse, dans lequel le mythe grec se vide, par le texte de Noll, de toute signification qui aurait pu lui être attribuee précédemment, pouvant alors être revêtu d'autres approches de lecture.

MOTS-CLÉS: Noll; Narcisse; Blanchot; Auteur; Écriture. 
Nas narrativas do escritor João Gilberto Noll, o narrador é predominantemente anônimo, solitário, e destituído de relações familiares e sociais, narrando a sua trajetória em uma errância sem origem, itinerário ou destino. São personagens masculinos, não-nomeados e desprovidos de contornos precisos, indefinidos pela voz que os enuncia. $\mathrm{O}$ narrador nolliano é, assim, uma voz sem nome, por trás de um rosto que vacila entre o desejo de negação da própria imagem e o anseio de transformação em outro corpo que o sustente. Nos romances Bandoleiros e Solidão continental essas recorrências que envolvem o narrador de Noll se estendem para a questão da elaboração da escrita literária, pois seus narradores são escritores que de forma direta ou indireta lidam com o fazer literário nessas narrativas.

Nas obras que são elaboradas dentro das narrativas nollianas acima destacadas, esses narradores problematizam a relação do autor com a obra no decorrer de seu desenvolvimento seja na não-nomeação dos personagens, que envolve a recorrente ocultação do narrador pela ambígua nomeação de João, ou ainda na recusa do narrador pela sua própria imagem e a busca do seu reflexo no outro. Essas ações provocam a oscilação, o espelhamento e a metamorfose entre autor e narrador através da indefinição e da instabilidade que são próprias da escrita de Noll, escrita que se desenvolve na ambiguidade e que se movimenta em direção a si própria, se fazendo ver pelos movimentos das obras en abyme que esses narradores desenvolvem no decorrer das narrativas em questão.

A ambiguidade característica da escrita nolliana me permite uma leitura dessa problematização da relação da autoria ao longo de seu discurso, perpassando o mito grego de Narciso. Porém, na minha leitura, o texto de Noll esvazia o sentido previamente estabelecido do mito e o direciona para uma elaboração interna da sua própria linguagem. Portanto, o mito não é mais percebido como um pensamento que explica a origem do mundo, de sua composição e de sua ordem, transmitido pelas narrativas imaginárias e dramáticas das teogonias e cosmogonias antigas, nas quais as figuras das Potências primordiais narravam o aparecimento do mundo e as instituições da ordem, formando a trama dos mitos. ${ }^{1}$

Se no pensamento mítico grego, como afirma Jean-Pierre Vernant, o original e o primordial são revestidos de majestade e de mistério, iluminando e transfigurando o cotidiano: "Para o pensamento mítico, a experiência cotidiana se esclarecia e adquiria sentido em relação aos atos exemplares praticados pelos deuses 'na origem "; ; $;$ nos textos de Noll, o olhar sobre o mito grego, especificamente o de Narciso, se distancia de qualquer sentido que the fora previamente estabelecido, e por essa fissura causada pela releitura do mito o direciona para a elaboração da escrita literária. Sigo aqui o caminho traçado pelo escritor francês Maurice Blanchot, que
1. VERNANT. As origens do pensamento grego, p. 109.

2. VERNANT. As origens do pensamento grego, p. 110. 
3. BLANCHOT. O espaço literário p. 12

4. BLANCHOT. A parte do fogo, $\mathrm{p}$. $327-328$.

5. A ocultação da identidade do narrador nolliano pela oblíqua nomeação de João acontece nas obras $A$ fúria do corpo, Berkeley em Bellagio, Canoas e marolas e no conto "João", de $A$ máquina de ser - além de Bandoleiros e Solidão continental, que serão trabalhadas neste artigo. percebe o mundo pressuposto pela literatura como um mundo autossuficiente, com bases próprias que não estão subservientes ao mundo real, mundo do autor que a produziu:

Entretanto, a obra - a obra de arte, a obra literária - não é acabada nem inacabada: ela é. O que ela nos diz é exclusivamente isso: que é - nada mais. Fora disso, não é nada. Quem quer fazê-la exprimir algo mais, nada encontra, descobre que ela nada exprime. ${ }^{3}$

Assim, a literatura deixa de ser um modo de representação e perde a possível referência com o mundo real, tornando-se a apresentação de si mesma como um mundo possível e diversificado, pautado pela ambiguidade: "Na literatura, a ambiguidade é como entregue aos seus excessos pelas facilidades que ela encontra, e esgotada pela extensão dos absurdos que pode cometer" ${ }^{4}$ Desse modo, nas obras de Noll aqui analisadas, a ambiguidade se faz pela oscilação, espelhamento e metamorfose entre autor e narrador, refletida nas obras en abyme que se desenvolvem nesses romances e relacionada a autocontemplação de Narciso. Essa ambiguidade é intensificada pela oblíqua nomeação de João, nomeação que dá a ver ao mesmo tempo em que oculta a figura do narrador/autor nolliano. ${ }^{5}$

Portanto, o narrador anônimo, que oculta a sua identidade e se disfarça pelo jogo da oblíqua e indireta nomeação de João, encontra ainda nesse referente a possibilidade de ocultação da sua imagem, passando a ser, assim, além de uma voz sem nome, uma voz sem rosto. Dessa forma, por esse movimento dos narradores de Noll, se entrevê o despojamento daquele que escreve por meio daquilo que se escreve, quando o escritor não pode mais dizer "eu" sem dizer do outro, o "ele", pela exigência da escrita que o desapropria e o torna Outro. Jogado para fora de seu mundo, o escritor é retirado de sua vida e entregue a esse espaço da ausência de tempo, sendo entregue, assim, ao movimento da escrita que, nas palavras de Maurice Blanchot, é a entrega, pelo que se escreve, a uma afirmação sobre a qual aquele que escreve é carente de autoridade:

Escrever é, então, quebrar o vínculo que une a palavra ao eu, assim como é romper com a relação do entendimento dessa palavra que digo para com aquele a quem digo, é a passagem do Eu para o Ele: "Ele' sou eu convertido em ninguém, outrem que se torna o outro, é que, do lugar onde estou, não possa mais dirigir-me a mim e que aquele que se me dirige não diga 'Eu', não seja ele mesmo". ${ }^{6}$

É por essa passagem do "Eu” ao "Ele" que, em Bandoleiros, João, a recorrente designação que encobre a identidade do narrador nolliano, se estende para outro personagem, para a figura que o narrador busca como a sua imagem refletida. Nessa obra, o narrador é um escritor brasileiro que tem uma experiência de vida no exterior, em Boston, sem um grande investimento financeiro por trás. Distante da condição de escritor renoma-
6. BLANCHOT. O espaço literário, p. 12.
EM TESE
BELO HORIZONTE
v. 22
N. 2
MAIO-AGO. 2016
SOUZA. Noll contempla Narciso: a escrita em reflexo
P. $227-244$ 
7. NOLL. Bandoleiros, p. 9.

8. NOLL. Bandoleiros, p. 75.

9. NOLL. Bandoleiros, p. 7.

10. NOLL. Bandoleiros, p. 159. do, o narrador de Bandoleiros se autodefine como "um escritor desiludido": "Eu andava arrasado porque meu último livro, So macabro, não tinha vendido nada. Alguns críticos destacaram o romance no panorama do ano. Mas eu não tinha leitores". Desesperançado e sem recursos, vive de traduções, consumido pelo que chama de "um abscesso no pensamento", que o prende a uma apatia extrema.

Esse narrador anônimo tem como seu antípoda um grande amigo, também escritor, João: "João é um escritor guerreiro. Acabou de lançar um romance esperançoso". ${ }^{8}$ A narrativa de Bandoleiros se inicia por João: “João está na minha frente. Pálido. Pergunta se não quero fazer café. Digo que sim", e em João se finaliza: "E eu fui. Abandonei a mala e fui, devagarinho, gozando cada passo, e cheguei perto do vidro, e João estava ali do outro lado, com seu braço bonito dobrado para cima, a mão contra o vidro, e eu fui ali, toquei minha mão no vidro, justo na mão de João". ${ }^{10}$ A nomeação João se dá em Bandoleiros como o ponto de partida e o ponto de chegada da narrativa, encurralando o narrador que, entre esses dois extremos, percorre o fio narrativo tendo também João como o seu ponto de atração, pois para o narrador dessa obra João é o eixo que o atrai e para o qual ele se direciona em um movimento determinado e substancial.

Assim, a nomeação João demarca os limites gráficos dessa narrativa e se multiplica no entremeio desses limites como se essa nomeação, duplicada, funcionasse como dois espelhos dispostos frente a frente, reproduzindo, assim, reflexos de João que ecoam no anseio do narrador pela imagem que o atrai e o fascina:

Seria minha chance de abandonar a mala no piso do saguão da Alfândega, e de mãos soltas ir ao encontro de João. [...] Pensei que a curiosidade humana acabaria por me destruir de vez ainda antes de eu conseguir ver João. [...] Era preciso traçar um plano de como levar aquele chumbo até onde João estivesse. [...] Implorei às Alturas que logo depois da curva fosse a saída do saguão da Alfândega e que João estivesse ali, me esperando. Disse baixinho que não queria outra coisa senão ver João, mesmo que em troca esse fosse meu último pedido. [...] se eu pudesse adormecer ali, agora, ouvindo João contar com seu jeito quieto e ao mesmo tempo apaixonado... [...] E eu não queria me enredar em explicações, queria, isso sim, ter João na minha frente. [...] Do outro lado do vidro, ali, a meia dúzia de passos, João me sorria. [...] Eu apenas conseguia ficar ali, de joelhos sobre a mala, olhando João, esperando que algum sorriso me aflorasse, qualquer sinal que me trouxesse de volta a ele, João. Não, não havia nenhuma tristeza para que eu não conseguisse sorrir. Eu estava mesmo era exultando lá por dentro com João. [...] Apenas sei que, de joelhos sobre minha velha mala, me baixou a sensação de que João ia morrer. Só isso: aquele mesmo João do outro lado do vidro, com seu braço 
11. NOLL. Bandoleiros, p. 155-159, grifos meus. ainda bonito e tudo, esse João vai morrer. [...] Mas passei a mão pela boca, como a me lembrar que o melhor agora era sorrir, mostrar a João que eu estava explodindo de alegria por revê-lo. Porque João sorria, e eu que desse logo fim a meus mórbidos pressentimentos. [...] Porque João sorria, e não importava coisa alguma que ele fosse morrer. João vai. Eu vou. Todos nós vamos morrer. Então, o que importava era aquilo mesmo - eu devolver esse largo sorriso para João, que está ali, do outro lado do vidro, me sorrindo. E eu fui. Abandonei a mala e fui, devagarinho, gozando cada passo, e cheguei perto do vidro, e João estava ali do outro lado, com seu braço bonito dobrado para cima, a mão contra o vidro, e eu fui ali, toquei minha mão no vidro, justo na mão de João. ${ }^{11}$

O narrador é assim atraído para a imagem que toma como reflexo de si, a imagem de João, com seu braço bonito e a mão a tocar o vidro da sala de desembarque do aeroporto, como um espelho onde, do outro lado, o narrador toca a sua mão, unindo-se à imagem que o atrai e na qual se faz refletido. A duplicação do narrador em João acompanha o espelhamento da narrativa de Bandoleiros, que se desdobra nas experiências vividas por seu narrador entre o Brasil e os Estado Unidos, duplicando os personagens e as ações que estes vivenciam nas duas estâncias narrativas que se refletem no decorrer do enredo, pois o narrador desta obra é também um escritor que elabora uma obra dentro da obra, se repartindo nas figuras do autor e do seu personagem elaborado.
A narrativa de Bandoleiros se inicia em Porto Alegre, após o retorno do narrador ao Brasil, nos minutos que antecedem a morte do seu grande amigo, o escritor João. Prossegue se voltando para o passado, ao narrar sem continuidade os momentos posteriores ao falecimento do amigo, vistos então como já vividos: o seu luto, a volta de sua esposa, Ada, dos Estados Unidos, o fim de seu casamento e a publicação do romance Sol macabro, a obra que o narrador elabora no decorrer do enredo: antes, durante e depois da sua estadia no exterior. Contudo, essas ações, como por exemplo, as fases do casamento do narrador com Ada, entre Porto Alegre e Boston, que são por ele narradas e que entrecortam suas experiências no decorrer da narrativa, constituindo o enredo de Bandoleiros, também fazem parte do material de elaboração do romance que então se fazia por ele dentro da obra:

No silêncio da biblioteca armo intrigas para meu próximo romance. De alguma forma Ada será a personagem central. A mulher do escritor é uma infeliz. Vive sendo sugada por ele. Bastou um gesto, uma palavra, um certo olhar, que pronto!, lá está a infeliz mulher do escritor transposta para o papel. ${ }^{12}$

As ações do narrador com Ada não se definem entre a sua experiência própria e o registro dessa experiência na sua elaboração ficcional, pois, assim como a sua esposa é transposta para o papel na escrita do seu romance, todas as fases do seu casamento por ele descritas também o são, uma vez que se desdobram no 
espelhamento das ações vividas pelo narrador nos movimentos de seus personagens. Estreitada a linha que separa as duas estâncias narrativas, uma se sobrepõe na outra, e a ação que se desenrola nas linhas do livro que o narrador elabora passa a ser o elemento temporal que define não só o tempo da sua escrita mas também o tempo da escrita no qual ele está inserido.

Dessa forma, a fase final do seu casamento, descrita pelo narrador através de cogitações e lembranças sobre os motivos derradeiros que culminaram na sua separação, é logo em seguida por ele suspendida, uma vez que já pertence àquele outro tempo, ao tempo de sua elaboração escrita: "Mas por enquanto nada disso aconteceu. Por enquanto ainda escrevo Sol Macabro, e nos intervalos olho o calor pela janela do escritório". ${ }^{13}$ O fim do seu casamento com Ada acontece concomitantemente com o fim da escrita de seu livro, portanto, com o livro ainda em elaboração, o que "ainda não aconteceu" é o que ainda não foi escrito.

De uma forma também duplicada, e até mesmo ambivalente, se desenvolve o relato de seu contato com o misterioso americano Steve, um personagem que surge inicialmente apenas pela voz, em um telefonema anônimo e ininteligíve que assusta o narrador e o leva a uma errância de angústia e bebedeira pelas ruas de Porto Alegre. O pânico causado no narrador pelo insólito telefonema, que o desespera e o faz fugir, finda por levá-lo ao encontro do americano dono da voz que lhe causa o inexplicável e súbito pavor: depois de beber muito, o narrador pega um ônibus aleatoriamente e dá em uma cidade com ares de pueblo mexicano, Viamão, onde então conhece Steve. Bebem juntos, Steve conta ao narrador sua vida, agridem-se, Steve tenta aniquilá-lo, o narrador foge no deserto, sucedem-se cenas desconexas e sem linearidade, Steve é quase morto pelo narrador, quando, então, subitamente, este reconhece o estrangeiro como sendo o homem que conhecera no último dia de sua estadia em Boston.

A narrativa então se direciona para esse passado recente, e um novo primeiro encontro com Steve é narrado: "A primeira vez que vi Steve tomava minha cerveja. Sentado junto a um balcão almofadado de Bar", ${ }^{14}$ assim como a sucessão insólita de acontecimentos que resulta na similar tentativa de Steve de matar o narrador e no semelhante revide quase fatal que o americano sofre. A narrativa, assim, apresenta detalhes em cada relato sobre o encontro com o americano que se assemelham, mas que se distanciam por peculiaridades, como se oriundas, talvez, sem uma definição exata, ora da narração de Bandoleiros, ora de Sol macabro, o livro dentro do livro. Os personagens Ada e Steve se duplicam como reflexos, imagens refletidas em um espelho do qual não se pode definir de que lado da superfície é a do mundo do narrador ou a do mundo que se desenvolve na escrita do seu romance. 
15. NOLL. Bandoleiros, p. 75

16. FRONTISI-DUCROUX; VERNANT. Dans l'eil du miroir, p. 253. No original: “L'écho est sur le plan auditif ce qu'est le reflet sur le plan visuel. II renvoie et repete, sous forme de Double, les paroles mêmes qui viennent d'être prononcées". Todas as traduções da obra Dans l'œeil du miroir são de minha autoria.

17. FRONTISI-DUCROUX; VERNANT. Dans l'œil du miroir, p. 211. No original: “On credite habituellement Ovide d'avoir le premier amalgame l'histoire d'Echo à celle de Narcise, redoublant ainsi, sur le plan sonore, le motif visuel du reflet."
Paralelo aos personagens duplicados Ada e Steve, há João, o grande amigo do narrador, escritor esperançoso e seu antípoda: "Quando eu falava de meus livros João respondia: tudo bem, mas por que esse talento todo empregado numa amargura corrosiva?" 15 João é a imagem que atrai o narrador e na qual ele se quer refletido, assim como é o nome que dá eco ao som por ele enunciado exaustivamente. A usual nomeação sob a qual os narradores de Noll se ocultam, João em Bandoleiros é então duplicada na imagem e no som, se revestindo de duplo aspecto, pois se trata de ver e ouvir unindo assim os planos auditivos e visuais, pois, como enfatiza Jean-Pierre Vernant: "O eco corresponde, no plano auditivo, ao reflexo no plano visual. Ele devolve e repete, de forma duplicada, as próprias palavras que vêm sendo pronunciadas". ${ }^{16}$

A união desses efeitos que a nomeação de João sugere em Bandoleiros remete o texto de Noll à mitologia grega, pois o ponto de união da imagem e do som se origina, ainda segundo Vernant, no mito de Narciso. Na inviável história de amor do mito, a ninfa Eco, totalmente tomada por uma paixão improvável de ser correspondida pelo jovem e belo Narciso, é reduzida a ser somente o reflexo das palavras que profere a boca do seu amado. Françoise Frontisi-Ducroux enfatiza que: "Atribui-se a Ovídio a junção dos mitos de Narciso e Eco, intensificando assim, sobre o plano sonoro, o motivo visual do reflexo". ${ }^{17}$
Em Metamorfoses, Livro III, Ovídio narra a paixão da ninfa pelo belo jovem. Por ajudar a ocultar os amores de Zeus com as outras ninfas, Eco é condenada por Hera a ser apenas uma repetição das palavras alheias. Perdida de amor pelo belo Narciso, Eco o persegue pelos campos, sempre se ocultando, impedida de lhe proferir as palavras de amor que lhe consomem o peito. Desviado dos colegas de caça, Narciso por eles clama, tendo como retorno o reflexo de suas próprias palavras que a jovem repetia. Inicialmente intrigado pelo fenômeno vocal que o persegue, Narciso, ao vislumbrar a imagem da voz que o iludia pelo reflexo de sua própria voz, dela foge firmando-lhe o juramento de ela nunca poder retê-lo nos braços.

Desdenhada, Eco se isola e definha até de si restar apenas a voz. Um dos muitos rapazes e moças que se iludiram por Narciso roga a Nêmesis um castigo como punição para o belo e indiferente jovem. Profetizado por Tirésias que vida longa teria se nunca conhecesse a si próprio, Narciso, movido pela deusa da vingança, debruça-se sobre uma fonte e apaixona-se pela imagem que vê refletida na água:

Quem és? Vem cá! Rapaz sem par, por que me iludes? Aonde vais sem mim? Em beleza e idade somos pares, e até mesmo as ninfas me amaram. Esperança me dás com teu semblante amigo; quando te estendo os braços, teus braços me estendes; 
quando rio, sorris; sempre vejo em ti lágrimas, se lacrimejo, e ao meu aceno tu assentes; e, pelo movimento de teus belos lábios, colho palavras que aos ouvidos não me vêm. ${ }^{18}$

Narciso ama perdidamente esse outro, objeto incorpóreo, sombra em vez de corpo. Quando, então, finalmente percebe tratar-se de sua própria imagem refletida, já não pode mais dela se afastar e definha se embevecendo do seu próprio reflexo. De Eco restou apenas a voz, de Narciso, a imagem, que ainda antes de sua entrada no Hades, ele mira nas águas do Estige. Na narrativa do mito, os dois personagens estão em uma relação de opostos complementares, de algo que permanece em si mesmo e de algo que permanece no outro, pois Narciso definha à beira da fonte impossibilitado de se distanciar de sua imagem refletida, enquanto Eco só subsiste como duplicação do que é pronunciado por seu amado.

Em Bandoleiros, a união dos efeitos semânticos da imagem e do som reunidos no mito grego se concentra, pelo reflexo e pelo eco, na imagem e no nome de João. Porém se no plano sonoro, tal qual Eco, o narrador subsiste pela repetição exaustiva da nomeação do outro que almeja e ecoa no plano visual o texto de Noll o movimenta no sentido contrário àquele simbolizado por Narciso, o da permanência em si mesmo, pois o narrador busca a vivência no seu oposto, ao negar o seu próprio reflexo e tomar o outro como a

imagem de si. A rejeição do próprio reflexo é uma recorrência para os narradores nollianos, o que põe o espelho como um elemento sempre presente nas obras de Noll, e como enfatiza Françoise Frontisi-Ducroux: "Qualquer análise das crenças relativas ao espelho leva inevitavelmente ao mito de Narciso". ${ }^{19}$ Entretanto, mais uma vez a simbologia do mito é subvertida no texto de Noll, pela relação entre o narrador e a sua imagem que se dá de forma antagônica à da contemplação e do desejo de a ela se unir que ocorre no mito de Narciso: "Eu parecia ter sumido um pouco mais. Só se viam as olheiras, os lábios esbranquiçados, ressequidos, e minha imagem diluindo-se em vertigem" ${ }^{20}$

Desse modo, o narrador de Noll, tal qual um antinarciso, substitui a sua imagem especular, unitária e em vias de decomposição, pela imagem do outro, seja como autor, nas possibilidades de diversificação dessa imagem nos muitos Eus elaborados na sua escrita, seja como personagem, na busca da sua imagem em outro corpo que a sustente. A busca do narrador pela imagem do outro é o movimento que leva o narrador de Solidão continental pelos espaços multiplicados de uma narrativa refletida, na qual, mais uma vez anônimo, solitário e errante, esse narrador é igualmente um escritor que se movimenta entre o Brasil e o estrangeiro, os Estados Unidos, se dividindo-se entre a intenção da escrita de seu primeiro romance e as aulas de português para estrangeiros que ministra tanto no exterior quanto no Brasil.
19. FRONTISI-DUCROUX; VERNANT. Dans l'œil du miroir, p. 200 No original: "Une analyse des
No croyances relatives au miroir mythe de Narcisse".

20. NOLL. Bandoleiros, p. 66 
Nessa obra, a indefinição dos mundos pelos quais transita o seu narrador é difundida pelos cenários que se alternam e se sucedem subitamente, na multiplicação de tempos e espaços que se propagam como reflexos de reflexos, derivando nos muitos personagens secundários que surgem e desaparecem nos caminhos desse narrador. A narrativa de Solidão continental se inicia em uma tarde de inverno em Chicago pela busca desmotivada do seu narrador por certo hotel Bismarck, local onde ele vivera um caso amoroso, há 28 anos, com um rapaz chamado Bill. Desmotivado, porém ansioso, encontra o hotel procurado que, no entanto, apesar do espaço visivelmente idêntico àquele do seu passado, não era mais o mesmo, pois quinze anos atrás se tornara o hotel Allegro. A nomeação dá ao espaço uma ambivalência temporal, pois o delimita em um ponto entre o passado que o narrador buscava, aparentemente perdido, e o momento presente que se lhe apresenta desapontador, pois agora transformado.

Entretanto, perante o seu visível desapontamento, o recepcionista do Allegro surpreende o narrador pela sugestão de uma compensação pela troca dessa mudança de nome: "Havia no entanto em seu semblante algo escuso, como se estivesse preparando uma ilusão certeira para me vender. [...] Depois ele veio com um ar de astúcia, a ponto de sugerir o que rever daquele espaço, o que sonhar, tocar, restituir". ${ }^{21}$ O narrador aceita a oferta do escuso rapaz, seguindo-o na intenção dessa provável ilusão que o leva justamente para a mesma suíte onde estivera há 28 anos com seu amante do passado, onde então o narrador é surpreendido por uma inesperada aparição, iniciando a dualidade da narrativa de Solidão continental:

Bill, simplesmente o mesmo que eu conhecera vinte e oito anos atrás, aquele mesmo que na época tinha seus 29 anos de idade... O que eu tinha então também. Mas ao invés de Bill trazer os sulcos do tempo feito a minha face, ele se rejuvenescera milagrosamente. ${ }^{22}$

A suíte se dá como o espaço intermediário entre os dois mundos, o do passado e o do presente, espaço de dualidade que sobrepõe os tempos e funde o hotel Bismarck no hotel Allegro, porém pondo em simetrias opostas os personagens em comum nessa duplicidade, o narrador e seu parceiro nas direções contrárias que cada um tomou em relação à passagem do tempo. Reforçando a descrição de si mesmo e de Bill apenas pela data do seu encontro, há 28 anos, e pela idade que eles tinham em comum, 29 anos, o narrador enfatiza a juventude de ambos como o elo de similitude entre os dois. Naquela suíte, em uma determinada data, ambos com a mesma idade, vivenciaram um ardoroso caso de amor, e o narrador se dirigia ao passado, ao hotel Bismarck, no momento presente, no hotel Allegro, à procura da lembrança de Bill. Contudo, a sua busca pelo antigo parceiro, apesar de um aparente retorno às lembranças, se mostra como a busca
EM TESE
BELO HORIZONTE
v. 22
N. 2
MAIO-AGO. 2016
SOUZA. Noll contempla Narciso: a escrita em reflexo
p. $227-244$ 
pela imagem do seu reflexo, na tentativa da possibilidade de se reconhecer no outro:

[...] eu, um homem hoje com outra idade, não mais o rapaz mas o senhor insuspeito [...] que vinha atrás de algum sobrevivente como ele, um outro que também estivera naquele recinto no mesmo quarto na mesma data, ele vinha à procura dessa figura, um homem como ele, não mais um rapaz, alguém que não teria medo de contemplar hoje em suas pequenas ruínas. ${ }^{23}$

O insólito Bill, na sua peculiar condição de homem que revertia a ação natural do tempo, rejuvenescendo ao invés de envelhecer, se estende ao polo oposto ao do narrador que já se depara com os primeiros sinais da velhice - em uma juventude enfermiça que o coloca em um ponto anterior àquele do caso vivido pelos dois há 28 anos. Aquém e além do vigor da juventude, quando ambos se refletiam tal Narciso e a sua imagem refletida nas águas da fonte: "Em beleza e idade somos pares", ${ }^{24}$ Bill e o narrador se distanciavam do momento vivido na suíte do hotel Bismarck, cristalizado no tempo pelas lembranças do narrador. A incomum aparição de Bill, na sua forma física peculiar, o distanciava da realidade do narrador, pois suas características o aproximavam mais de um devaneio do que de uma existência real: "A sua nudez parecia uma condição definitiva, a minha impressão era de que ele não fazia vida social, não andava pelas ruas e habitava uma espécie de UTI etérea, em algum lugar onde nem mesmo uma fantasia tresloucada ousava imaginar" ${ }^{25}$

A peculiar imagem de Bill leva o narrador à possibilidade de sair de sua persistente realidade e adentrar em um mundo flutuante, conduzido pela imaginação, fora da vista externa, já que vindo de uma projeção interior, espaço que o narrador usufruía desde criança como um refúgio para o seu alheamento, o mundo da sua criação: "Saí do meu ponto intervalar vendo o corpo que surgia ainda embaçado, como se eu precisasse de um tempo para verificar o mundo às claras - aquele mundo realmente posto no lado de fora agora já quase dominado pela minha percepção" ${ }^{26}$ Dividido entre o real e o ilusório, o narrador segue o mundo por ele projetado, pois Bill, em sua aparência incomum de nudez permanente, desaparece pelo mesmo banheiro da suíte do qual surgira. Ou encolhera ao estado anterior ao do feto, ou se evadira pelo vaso sanitário, trilha que o narrador escolhe para tentar encontrá-lo:

Enfiei a cabeça no vaso e apertei o botão da descarga. Meus cabelos e testa encharcados. Agora, sem as cataratas a rolar no sanitário eu vi a minha imagem no lago calmo do fundo. E saltei. Eu me despedia da renitente realidade na qual nos aferramos para sobreviver.

Então, sim, eu saltei. ${ }^{27}$
25. NOLL. Solidão continental, p. 22.

26. NOLL. Solidão continental, p. 18
EM TESE
BELO HORIZONTE
N. 2

MAO-AGO. 2016 
O narrador se enfia no vaso sanitário à procura de Bill, mas o que vê no fundo do vaso, "no lago calmo", é a sua própria imagem refletida. Uma imagem que, além de não ser mencionada por características de deterioração, não o repudia e, ao contrário, o atrai ao ponto de nela ele afundar em um salto. $\mathrm{O}$ texto de Noll, na minha leitura, assim relê o mito de Narciso, subvertendo os seus valores. O narrador, um homem em suas pequenas ruínas, trazendo na face os sulcos do tempo, se volta em direção às suas lembranças, na busca do amante do passado que então lhe espelhava em juventude e beleza, no anseio de reencontrar nele o reflexo da sua imagem atual, buscando, assim, o reflexo de si no outro. A peculiar figura que encontra, no entanto, se aproxima mais de uma projeção ficcional, vinda, como o próprio narrador sugere, de um espaço só possível pela imaginação da fantasia. Na procura por esse objeto ilusório, o narrador encontra a si próprio refletido em um lago calmo, tal como o belo jovem do mito grego, porém, não em uma "fonte argêntea de águas límpidas", ${ }^{28}$ mas no fundo de um vaso sanitário.

O mergulho na imagem leva o narrador a adentrar ainda mais nas suas possibilidades de imaginação, uma vez que ele encontra do outro lado desse espelho um mundo totalmente invertido no tempo e no espaço, pois emerge na piscina de outro hotel, Satyricon, em um clima quente de verão "tipo Miami", habitando um corpo jovem e vigoroso, com uma mulher de biquíni a lhe sorrir da borda da piscina: sua esposa
Elvira, que ele intentara abandonar 28 anos atrás para viver o caso com Bill. A dualidade dos mundos que a suíte do hotel Bismarck/Allegro possibilitava ao narrador se estende a um terceiro espaço, que reflete o anterior pela inversão: como duas faces contrárias de um mesmo espelho, a superfície do "lago" do sanitário e a superfície da piscina interligam dois mundos, mundos opostos que põem de um lado o frio de Chicago, a velhice e um Bill etéreo e do outro o verão da Flórida, a juventude do narrador e sua esposa Elvira, quando, então, não se pode mais discernir dentre eles qual pertence ao passado ou ao presente (ou ao futuro projetado) e qual pertence ao mundo do narrador ou ao mundo da sua ilusão.

O narrador salta no fundo do lago do vaso sanitário para fugir da sua então renitente realidade, porém, emerge em um espaço e em uma situação dos quais também deseja se evadir. Não quer a vida com Elvira, pois intenta a continuidade da busca por Bill que, no entanto, só pode se dar em outra dimensão, pois a busca pelo antigo amante, inicialmente pertencente ao estado da vigília, se inverte para a dimensão do sonho, estado estreitamente próximo à imaginação, ao ato da criação ficcional:

Entre ela e um prato de salada com um bom azeite, um peixe, eu preferiria o prato, depois a sesta e o perigo de acordar no quarto do Bismarck ou do Allegro, tanto fazia, olhando da janela Chicago coberta de neve, eu com a mão aberta contra 
o vidro, sonhando estar num avião, rumando para outra cidade onde eu pudesse encontrar Bill exatos vinte e oito anos atrás, com seus 29 anos, por aí, acercando-se do meu corpo ainda jovem também, como aqui, com essa mulher, para quem digo agora ao ouvido uma palavra apaixonada, outra sublime, outra criteriosamente chula, agora só um sopro em seu ouvido, é Bill quem pede mais, é Bill, não ela. ${ }^{29}$

Invertida também se mostra a reação do narrador de Solidão continental diante de sua imagem refletida, reação contrária à usual rejeição dos outros narradores nollianos. A incomum atitude desse narrador no ato de se refletir pode ser pensada pelo objeto refletor. Diferentemente dos demais narradores de Noll, que repudiam a imagem refletida em espelhos, este narrador mira o seu reflexo, sem o angustiante desapontamento, em um espelho d'água; situações aparentemente idênticas no ato de se ver pelo reflexo, mas que, no entanto, diferem radicalmente no efeito dessa visão, um vez que ela também deriva do seu objeto refletor, como en fatiza Gaston Bachelard: "Os espelhos são objetos demasiado civilizados, demasiado manejáveis, demasiado geométricos são instrumentos de sonho evidentes demais para adaptar-se por si mesmos à vida onírica". ${ }^{30}$

Para Bachelard, pensando em uma utilidade psicológica dos espelhos naturais, a água é um elemento que naturaliza a nossa imagem, ao devolver um pouco de inocência e naturalidade à nossa contemplação íntima. À beira da fonte, onde Narciso se sente naturalmente duplo, ele estabelece o diálogo sem fim da imaginação criadora com seu modelo natural: "Diante das águas, Narciso tem a revelação de sua identidade e de sua dualidade, a revelação de seus duplos poderes viris e femininos, a revelação, sobretudo, de sua realidade e de sua idealidade".

Dessa forma, a partir do salto na sua imagem, no mergulho que deixa para trás a renitente realidade, o narrador de Solidão continental adentra no mundo da sua imaginação, mundo pensado a partir das imagens por ele criadas, onde as ações se movimentam no ritmo que é usual na escrita de Noll, e também nas elaborações en abyme dos seus narradores-escritores. Doravante, pelo efeito da multiplicação de cenas, o narrador perpassa as alterações dos espaços narrativos, pelas cidades de Chicago, Cidade do México e Porto Alegre, além dos cenários indefinidos e oníricos, que se desdobram em uma velocidade que o surpreende: "De fato, tão radical foi o corte dessa cena para a seguinte que acho impensável que elas tenham se concatenado em sequências contíguas." 32 - multiplicação também refletida na sucessão de personagens que surgem e se evadem ininterruptamente: Tom, Mira, Frederico, Roberto e Amanda são pessoas de sexo, idade, nacionalidade e características diferentes que cruzam o caminho do narrador.
31. BACHELARD. $A$ água $e$ os sonhos, p. 25.
EM TESE
BELO HORIZONTE 
36. NOLL. Solidão continental, p. 50.

33. NOLL. Solidão continental, p. 34.

34. NOLL. Solidão continental, p. 40.

35. NOLL. Solidão continental, p. 47.
Em vias de elaborar o seu primeiro romance, esse narrador, assim como o narrador de Bandoleiros, é um escritor atento a tudo ao seu redor, na intenção de atrair o mundo, as pessoas e as situações que vivencia para o papel, para as páginas de sua elaboração escrita:

Eu seria uma nova testemunha da história. E receberia o assunto secreto de um homem igual a mim. Um homem que eu desejara ou desejava ainda, que eu podia apalpar se ele deixasse. Teria o inimigo no meu regaço. E poderia escrever o meu primeiro romance esculpindo a sua figura que naquele bar eu voltava, sim, a desejar inteira. ${ }^{33}$

Essa escrita ainda por vir, entretanto, já se faz perceber na narrativa de Solidão continental pela assimilação que o narrador faz de si e dos seus amantes no decorrer da sequência de cenas, "capítulos" nos quais ele se vê a si e aos demais como "personagens". Intentando inicialmente o reencontro com Bill, o narrador vai se deparando a cada cena com um novo personagem que o atrai, mas o distancia pelas insólitas situações que com eles vivencia, como se os personagens o desgastassem: "Precisava de recolhimento durante aquelas horas, esquecer a história de Bill, de Tom.". ${ }^{34}$ Porém, eles surgem continuamente, como se desdobrados, cada novo personagem dando continuidade ao anterior, aparecendo em sequência e povoando a trajetória do narrador: "Entrei no avião com uma profusão de coisas na cabeça. Bill, Tom, Mira, o que me sobrara de tudo aquilo?”35 Nessa sucessão incessante de personagens, por vezes, nome e gênero se confundem: "[...] preferi escapar pensando detidamente na língua inglesa, em Bill, Tom, Mira ou Miro, sei lá” ${ }^{36}$

É ainda pela imprecisão de sua narração que o narrador libera um ato falho e traz à tona o seu reflexo perdido, pois ao descrever um dos seus alunos americanos das aulas de Língua Portuguesa, Tom, um mórmon ex-combatente da Guerra do Iraque, um tipo descrito como gordo e peludo, portanto, fisicamente diferente do outrora esbelto e belo Bill, as nomeações se confundem: "Ele nesse instante me olhava, depois olhou para a sua farda camuflada como quem dissesse, era isso o que você pretendia, agora aproveite, sou todo teu, me agarre. Bill era o urso que eu contemplava nas revistas gays". ${ }^{37}$ Dessa forma, os amantes, personagens em escala, sucedem-se no reflexo do seu modelo original, Bill, a imagem que obceca o narrador e na qual ele se unira em reflexo, na juventude em comum, aos 29 anos, há 28 anos.

Esses personagens surgem, assim, como reflexos, criações do narrador, desdobrados na indefinição desses mundos nos quais ele transita, mas que, no entanto, apontam para o mundo de sua imaginação e criação literária, para a obra que na narrativa de Solidão continental está constantemente no porvir, na recorrente e anunciada intenção do narrador em iniciá-la, mas que, todavia, já se apresenta no decorrer
37. NOLL Solidão continental, p. 32 33 , grifo do autor. 
da narrativa, como o espelho paralelo que o absorve de sua realidade, mundo do qual ele deseja se evadir, inserindo-o em suas páginas como um reflexo ficcional: "Eu vivia entre fantasmas, pensei, e dessas companhias etéreas eu não queria me apartar. Os seres físicos não me ofereciam nada mais convincente do que essas presenças esquivas ao meu toque, geralmente caladas.... ${ }^{38}$

Inserido em uma linguagem que permite a pluralidade da significação, o narrador encontra no espelho o ponto de propagação dessas possibilidades, pois pela ação do espelho há, pelo menos, sempre mais do que um, e nesse mundo no qual o narrador emergiu, espelho refletido de espelhos, pluralizam-se as imagens pela potência multiplicadora dos mundos que se refletem através do dom da multiplicação que é próprio dos espelhos. O espelho possibilita a multiplicação dos seres, assim como a escrita literária possibilita a profusão dos personagens, e o narrador como o autor que elabora, mas também como o personagem que é elaborado, multiplica a si mesmo na sua interação com cada um desses reflexos por ele criados: "Eu sabia estar vivendo um momento de virada. Para o garoto me seguir eu precisaria negar o que experimentara até ali, ser outro". ${ }^{39}$

Desse modo, o narrador se multiplica na proliferação de sua ilusão criadora, na trilha dos reflexos dessas formas por ele elaboradas e nomeadas a cada nova cena de sua trajetória,

EM TESE personagens espelhados que lhe atraem pela imagem de beleza e juventude, mas que, no entanto, o refletem pelo oposto, pois, a exemplo de sua contemplação na imagem de Mira, o narrador sente que envelhece demasiadamente em face da garota, contemplando supostamente a sua própria imagem como antagônica à da bela e jovem adolescente. Como acontece usualmente ao narrador nolliano, que vê no reflexo do seu rosto a imagem da decrepitude, esse narrador, sem poder recorrer ao espelho, toma a visão que o outro personagem possa ter dele como a sua provável imagem refletida: "Será que a imagem que eu passava a uma adolescente poderia parecer a de um ancião?"40 Ao ver o narrador como um ancião, portanto acentuado em seus sinais de velhice e decrepitude iminentes, Mira perpetuaria a habitual visão que os narradores nollianos têm de sua imagem. A imagem que Mira possa ter do narrador passa a ser, então, para ele, o seu verdadeiro reflexo.

Mira funciona, assim, como um espelho para o narrador, porém a interpretação do objeto refletido não vem do espelho, mas do cérebro de quem nele se reflete que interpreta os dados fornecidos pela retina, como explicita Umberto Eco: "Ele não 'traduz'. Registra aquilo que o atinge da forma como o atinge". ${ }^{41}$ De acordo com Eco, a imagem especular, quando reflexo de quem nela se reconhece, leva em consideração as informações prévias que o objeto, aquele que se mira no espelho, tem de suas próprias feições, que interferem, mesmo que minimamente, na sua interpretação da
40. NOLL. Solidão continental, p. 44.

41. ECO. Sobre os espelhos e outros ensaios, p. 17. 

ensaios, p. 20. imagem refletida: "Mas é preciso considerar que a imagem especular não é uma duplicata do objeto, é uma duplicata do campo estimulante ao qual se poderia ter acesso caso se olhasse o objeto ao invés de sua imagem refletida". ${ }^{42}$

Através do possível olhar de Mira, sua elaboração ficcional, o narrador nos dá a possibilidade de vê-lo como o objeto visto pela imagem refletida. A jovem como espelho mostra ao narrador, na forma como ele então se "mira", a sua iminente deterioração, decorrente da velhice acentuada. Dessa forma, se refletindo em seus personagens, a narrativa do narrador de Solidão continental passa a se desdobrar em dois mundos opostos, que tem de um lado o multiplicado mundo da ilusão onde o narrador se reconstrói e no qual ele transita entre os reflexos de sua criação, mas que, no entanto, não o aparta definitivamente do outro mundo, o mundo de sua realidade renitente, para onde, por vezes, é levado pelo próprio movimento da sua escrita.

É assim que, a partir dessa imagem criada em face do personagem Frederico, a narrativa leva o narrador a oscila entre esses dois mundos opostos. Ao seguir o jovem para o campo, se distancia do mundo que reconhece como aquele das suas referências diárias, o da cidade de Porto Alegre, assim como as viagens aos Estados Unidos e ao México, indefinidas nas estâncias narrativas da obra. Rejeitando tudo que ficara para trás, descarta as anteriores tentativas de união aos demais personagens Bill, Tom, Mira, Roberto e Amanda, elegendo Frederico como a imagem ideal, aquela na qual ele se quer refletido: "Ao contrário desse período, eu agora contava com um corpo que realmente fazia pendant com o meu, um corpo entregue ao meu abraço". ${ }^{43}$ Esse corpo, semelhante, simétrico, fazendo "pendant" com o corpo do narrador, entretanto, devido a um inexplicável acidente, subitamente surge quase sem vida, prostrado à beira do rio no qual o narrador entra e se masturba, turvando com seu sêmen o tom prateado e translúcido do espelho lunar de suas águas, espelho que o narrador substitui, como objeto de contemplação, pelo ainda belo rosto de Frederico.

$\mathrm{Na}$ tentativa da salvação corporal do seu reflexo, o narrador leva o rapaz a um hospital, quando, então, sai do mundo indefinido no qual errava com Frederico e se depara abruptamente com aquele da sua outrora realidade cotidiana, o da cidade de Porto Alegre: "Entre mim e aquele cenário da Oswaldo Aranha havia como uma mucosa transparente doendo se eu tocasse. Não era possível vislumbrar aquele cenário com isenção". ${ }^{44}$ Mundo esse que aos poucos reconhece, mas que, no entanto, não aceita integralmente, pois diante da exigência do hospital pela sua identidade, abandona o rapaz e foge. A recusa em se revelar, pela nomeação, o leva a um período de angústia pela incerteza sobre a situação de Frederico. Depois de uma série de reviravoltas, é levado
43. NOLL. Solidão continental, p. 69 , grifo do autor. 
47. NOLL. Solidão continental, p. 91.

45. NOLL. Solidão continental, p. 88-89. desacordado para o mesmo hospital, quando, então, é despertado para as exigências da realidade pela insistência na revelação de sua identidade, que se pronuncia pela já habitual nomeação oblíqua de João:

[...] e a médica me perguntava pela milésima vez meu nome e eu precisava lembrar dele se quisesse me ver livre de seu jugo e eu tentei, respirei fundo e trouxe à tona um nome de quatro letras chamado João sem saber com conviç̧ão se aquele de fato era o meu nome mas era, não havia outro, João, repeti, e ela queria saber o nome completo, o sobrenome também, e eu respondo que assim é demais, que eu só tenho esse, nenhum mais. ${ }^{45}$

A nomeação insere o narrador no mundo de sua renitente realidade, mundo que intentara deixar para trás na busca por Bill, a partir do mergulho na sua própria imagem refletida no lago do vaso sanitário, mundo que ainda rejeita e que novamente é tentado a abandonar pela força da visão de uma imagem que o chama para o seu núcleo, a imagem de Frederico vivo: "Mas essa inquirição demoníaca foi soando cada vez mais longe, até sumir enfim como se capitulando diante do meu silêncio. Sacudi a cabeça e me concentrei na face de Frederico de novo resplandecente" ${ }^{46}$

Mais uma vez, o narrador se entrega a uma imagem, pois, consciente de que se trata de uma representação do rapaz, "[...] me veio uma tal certeza de que eu estava diante de uma estátua e não de uma carne fresca de alguém com a idade dele [...]", ${ }^{47}$ segue a imagem de Frederico para um espaço que se reproduz invertidamente refletido daquele do qual desejava se evadir. O ruído insistente do hospital, Porto Alegre e a identidade de João, o homem que jaz enfermo na maca, são presenças substituídas pelo seu inverso, no retorno ao espaço da natureza, já antes vivenciado por ele corporeamente com Frederico, espaço onde o narrador, restabelecido e ao lado de seu igual, estaria imune às vicissitudes de sua idade, no banho de rio onde as águas e a natureza lhe dariam outra memória que apagaria o passado, lhe possibilitando estabelecer "o diálogo sem fim da imaginação criadora com seus modelos naturais" ${ }^{48}$ o reino em comum para ele e seu reflexo, "[...] no lago onde o olhar de um no outro nos faria enfim espairecer de fato". ${ }^{49}$

Frederico leva o narrador ao espaço do silêncio, em um cenário natural que o revitaliza pela força oriunda da imagem do rapaz que ele segue destemidamente, pois a figura responde às suas demandas por um corpo igual ao seu, mesmo que, entretanto, esteja mais próxima do incorpóreo uma sombra intocável e inacessível que sobremaneira ainda o atrai e na qual ele se embevece:

O que era uma pequena humilhação diante do fato de eu responder, mesmo que provisoriamente, às minhas demandas por outro corpo igual ao meu? Pouco importava se eu não o
48. BACHELARD. $A$ água e os sonhos, p. 27.

49. NOLL. Solidão continental, p. 92 

277-278. tocasse, pois eu estava seguro de que ele tinha um cheiro, e esse cheiro vinha na brisa: já se confundia com as águas e com a areia ardendo nas solas dos passos. ${ }^{50}$

Tal qual Narciso, que "Enquanto bebe, preso à bela imagem vista, ama objeto incorpóreo, sombra em vez de corpo", ${ }^{51}$ o narrador de Solidão continental, na entrega à imagem por ele adornada, e que lhe propicia a possibilidade de se apartar da identidade e do cotidiano que usualmente lhe é indesejável, transpõe na sua obra literária a idealização que lhe permite adentrar em um mundo paralelo na busca pelo seu reflexo no outro, que se dá no mundo da ausência corpórea, do vazio e do silêncio, o mundo que se assemelha ao da imagem, pois, "A imagem pede a neutralidade e a supressão do mundo, quer que tudo reentre no fundo indiferente onde nada se afirma, tende para a intimidade do que ainda subsiste no vazio: está aî a sua verdade".$^{52}$ Nessa outra imersão do narrador, a narrativa apresenta então uma nova dualidade, na cisão entre o mundo material e o mundo ideal, espaço onde a presença se dá pela ausência, onde a imagem substitui o objeto, espaço que não permite a integralidade das coisas e dos seres:

Sei que me sentia mortalmente desfamiliarizado com o ambiente e que assim eu só poderia perceber o cão feito uma sombra que se alienara de sua matriz - seu corpo verdadeiro habitava uma fonte que, mesmo querendo, eu não podia al- cançar. Parecia haver um mundo onde as coisas se preservavam íntegras, mundo com o qual eu tinha rompido em consequência de uma doença qualquer..$^{53}$

O espaço ao qual o narrador é levado pela força da imagem do jovem Frederico se assemelha ao mundo flutuante provindo de sua projeção interior, derivado do estímulo de sua imaginação e produto de sua criação, que lhe permite a evasão para o plano da irrealidade pela força imagética da ficção, pois a força da imagem "[...] permite-nos crer, no âmago de um sonho feliz que a arte autoriza com demasiada frequência, que à margem do real e imediatamente atrás dele encontramos, como uma pura felicidade e uma soberba satisfação, a eternidade transparente do irreal". ${ }^{54}$

A imagem de Frederico, entretanto, se esvai, e o narrador se sente impelido a sair daquele mundo de silêncio, mesmo que incerto sobre a possibilidade de ainda ter acesso à outra metade de sua figura, ao corpo que jazia na maca do hospital. Por fim, sai da ilha da sua imaginação e retorna para a cidade, voltando ao seu apartamento, quando, então, outro personagem surge: Daiane, a sua empregada, o novo rosto que o olha e o corpo que se expande ao encontro do seu. O corpo no qual o narrador lentamente entra, seguido pelas reticências que finalizam a narrativa de Solidão continental e que apontam para a continuação da multiplicação de imagens
53. NOLL. Solidão continental, p. 101

54. BLANCHOT. O espaço literário, p. 278. 
que se dará nesse mergulho no novo personagem que atrai o narrador, através do corpo que ele penetra e que proliferará as imagens de sua ilusão, pelo reflexo dos personagens que surgirão refletidos em outras narrativas, motivadas pela escrita de um romance ainda por vir, mas que, no entanto, $j a ́$ se desenvolve no decorrer da busca desse narrador pela sua continuidade na imagem do outro.

\section{REFERÊNCIAS}

BACHELARD, Gastón A água e os sonhos: ensaios sobre a

imaginação da matéria. 2. ed. São Paulo: Editora WMF Martins Fontes, 2013.

BLANCHOT, Maurice. A parte do fogo. Tradução de Ana Maria Scherer. Rio de Janeiro: Rocco, 1997.

BLANCHOT, Maurice. O espaço literário. Tradução de Álvaro Cabral. Rio de Janeiro: Rocco, 2011.

ECO, Umberto. Sobre os espelhos e outros ensaios. Rio de Janeiro: Nova Fronteira, 1989.

FRONTISI-DUCROUX, Françoise; VERNANT, Jean-Pierre. Dans I’Gil du miroir. Paris: Éditions Odile Jacob, 1997.

NOLL, João Gilberto. Bandoleiros. São Paulo: Companhia das Letras, 1999.

NOLL, João Gilberto. Solidão continental. Rio de Janeiro: Record, 2012.
OVIDIO. Metamorfoses. Tomo I. Tradução de Raimundo

Nonato Barbosa de Carvalho. São Paulo: USP, 2010. Trabalho

disponibilizado no sítio: http://www.usp.br/verve/coordenadores/

raimundocarvalho/rascunhos/metamorfosesovidio-

raimundocarvalho.pdf 